\title{
Design Of Sales Application Models Using Quality Function Deployment Method And System Development Life Cycle: Case Study At Giriloyo Batik Tulis Center
}

\author{
$M$ Sulistyani ${ }^{*}, M$ As'adi , A N Zaman and $H$ Mahfud \\ Industrial Engineering, Faculty of Engineering, Universitas Pembangunan Nasional Veteran Jakarta, Indonesia
}

\begin{abstract}
Kampung batik Giriloyo is one of the centers of batik tulis production in Indonesia, located in Yogyakarta. During Covid-19, the number of visitors decreased from $600-1500$ people per day to 50 people per day. Based on data from the financial department of Kampung batik Giriloyo, sales of Giriloyo's products have also decreased by $67.78 \%$ from 1.997 billion to 643.3 million. In addition, based on data from Bank Indonesia, e-commerce transactions in Indonesia increased by 18,1\% (98,3 million transactions) with transaction values increasing by $9,9 \%$ (20,7 trillion) during covid-19. Based on these problems, by taking advantage of technological advances, the researcher proposed to design a sales application as an alternative to increasing the sales of batik products in Kampung Giriloyo. This study aims to determine the features needed by visitors in Kampung batik Giriloyo for application using the quality function deployment method to determine customer needs and the system development life cycle to design application models. The results of this study are 9 lists of customer needs for the application, the features for the application, and the prototype of the application.
\end{abstract}

Keywords: Quality Function Deployment, System Development Life Cycle, Sales Application Models

\section{Introduction}

Giriloyo batik village is a batik tulis community in Giriloyo hamlet, Wukirsari village, Bantul district, Yogyakarta, which focuses on selling hand-batik tulis products produced by 12 batik groups in Giriloyo. Each batik group consists of $20-80$ members. Based on the researcher's interview with the batik village manager, Ibu Khibtiyah, sales of batik products in 2020 experienced a drastic decline compared to 2019. The percentage of decreased sales reached $67.8 \%$ from 1.997 billion to 643.3 million. This happened because of the social restrictions imposed by the Yogyakarta government as a result of the 2019 Covid pandemic. Visits in the Giriloyo batik village also decreased from $600-1500$ people per day to 50 people per day. This has a direct impact on the sales of batik tulis products in Giriloyo village.

Based on these problems, Giriloyo batik village must improve a sales system that can cover a wide network so that sales turnover remains stable and can survive amid fierce competition.

We are currently entering the industrial era 4.0 where various areas of human life are connected through technology. Lately, many companies use technology to optimize their business processes. One of the uses of technology in this company is as a media approach to more consumers to increase sales. Based on data from Analytic Data Advertising (ADA), it shows that in 2020 the number of people in Indonesia who shop online has increased. In March online shopping figures increased $400 \%$ compared to the previous month. Based on data from Bank Indonesia in March, transactions for ecommerce increased by $18.1 \%$ to 98.3 million transactions with transaction values increasing by $9.9 \%$ to 20.7 trillion. This increase in online shopping is a good opportunity for businesses to increase sales and expand their marketing network. This opportunity can be applied to overcome the problems experienced by the Giriloyo batik village in marketing its products.

Based on the description above, the researcher proposes an application model design that can help the Giriloyo batik village to expand its product marketing network. The existence of this application can also facilitate the Giriloyo batik village for the reservation process of learning batik because of the shifting system implemented by the government. The design of this mobile application model aims to provide a better user experience to customers. This application is designed because data access is much faster than websites that take a long time to display data and HTML. For application transactions, the level of security is higher when compared to the website. Apart from that, application development can also be useful in brand

\footnotetext{
* Corresponding author : meitasulistyani@gmail.com
} 
development for companies and building customer loyalty. Applications can also be used for direct marketing channels so as to reduce promotional costs. Sales through the marketplace are subject to an administration fee of $1 \%-5 \%$. This value is high for sales costs only. So that the sales application design developed by Giriloyo batik village can be an alternative solution for the sales platform. In addition, the application was chosen to be developed because the data obtained can be used by the Giriloyo batik village in product development according to the criteria desired by the customer so that in the future the resulting product more in demand by customers.

\section{Literature Review}

\subsection{Mobile Application}

Mobile applications are software that can be run on mobile devices and have an operating system that supports independent software. The available mobile application distribution platforms are usually managed by the owner of the mobile operating system, such as Playstore (Apple App), Store (Google Play), Store (Windows Phone), and World (Blacberry App) (Siegler)

\subsection{Batik}

Batik is a technique of making patterns on cloth using a dip-covered technique using wax as a cover for colors and patterns (Doellah, 2002). Batik has been recognized as a world heritage. The United Nations (UN) Agency for Education, Science and Culture or UNESCO named batik as "Masterpieces of the Oral and the Heritage of Humanity" on October 2, 2009.

\subsection{Quality Function Deployment}

Quality Function Deployment (QFD) is a methodology that helps translate customer desires into design needs to ensure the output produced whether a product or process meets these needs (Erdil and Arani, 2019). QFD is often applied in the manufacturing industry, but QFD can also be applied to the service industry. QFD was developed in Japan in the late 1960s as a design process that helps incorporate customer voices into a product before production. The success of this method is measured in terms of reducing the initial cost and increasing the quality of the new product (Evans and Lindsay, 2015). The international standardization organization (ISO) proposes QFD in the ISO 16355 standard as a method for ensuring customer or stakeholder satisfaction and value with new and existing products.

\subsection{House Of Quality (HOQ)}

Quality Function Deployment consists of a set of matrices. This matrices are called the House of Quality (HOQ). HOQ takes customer needs and translates them into design needs. Below are the matrices contained in the quality function deployment:

\subsubsection{Voice Of Customer.}

Identifying customer needs and determining the degree of importance. For identifying customer needs, usually using survey, interviews, focus groups and other simillar methods. Customer needs that were originally "what" are converted into technical requirements to "how" in the next step.

\subsubsection{Technical Responses.}

To meet consumer needs, technical responses are used using the company's technical language. Each technical requirement can meet one or more customer requirements.

\subsubsection{Relationship Matrix.}

Relationship Matrix describes the relationship between voice of customer and technical response. To describe this relationship, it is done by giving weights as in the following table:

Table 1. Relationship Matrix Symbol

\begin{tabular}{ccl}
\hline Value & Symbol & \multicolumn{1}{c}{ Information } \\
\hline 0 & & Have no relationship \\
1 & $\Delta$ & Have a weak relationship \\
3 & 0 & Have a moderate relationship \\
9 & $\bullet$ & Have a strong relationship \\
\hline
\end{tabular}

\subsubsection{Customer Rating.}

The image or customer view of the company is called a customer rating

\subsubsection{Technical Correlation}

Technical correlation serves to describe whether technical responses have a relationship or not. The following is an explanation of the relationship between technical responses as show in table 2 :

Table 2. Technical Correlation

\begin{tabular}{|c|c|c|}
\hline \multicolumn{2}{|c|}{ Symbol nformatoin } & Describtion \\
\hline & $\begin{array}{l}\text { Strong } \\
\text { positive }\end{array}$ & $\begin{array}{l}\text { The relationship between technical } \\
\text { responses, positive is very strong. }\end{array}$ \\
\hline & $\begin{array}{l}\text { Medium } \\
\text { positive }\end{array}$ & $\begin{array}{l}\text { The relationship between technical } \\
\text { responses, positive is strong. }\end{array}$ \\
\hline & $\begin{array}{l}\text { Medium } \\
\text { negative }\end{array}$ & $\begin{array}{l}\text { The relationship between technical } \\
\text { responses, negative is strong. }\end{array}$ \\
\hline & $\begin{array}{l}\text { Strong } \\
\text { negatif }\end{array}$ & $\begin{array}{l}\text { The relationship between technical } \\
\text { responses, negative is very strong. }\end{array}$ \\
\hline
\end{tabular}




\subsubsection{Technical Priorities, Bencmarking and Targets.}

At this stage, determine the technicalities that must be prioritized by calculating Absolute Importance (AI) and Relative Importance (RI) using the following formula:

$$
\mathrm{AI}=\sum \begin{gathered}
\text { (customer importance } \mathrm{x} \text { technical } \\
\text { responses })
\end{gathered}
$$

$$
\mathrm{RI}=\frac{\text { AI/ technical responses }}{\sum A I \text { technical responses }}
$$

\subsection{System Development Life Cycle}

System Development Life Cycle is a method used for information system development that was first developed by systems analysts and programmers to build an information system. The following are the stages of the System Development Life Cycle :

1. System planning. At this stage, a review of the problems that form the basis for the formation of a new system is carried out. The purpose of this stage is to carry out an investigation or investigation to evaluate an existing problem.

2. System Analysis. System analysis is the decomposition of a complete information system into its component parts in order to identify and evaluate problems, opportunities, obstacles that occur and the expected needs so that improvements can be proposed (Yogiyanto, 1995). At this stage, PIECES and QFD analysis, requirement modeling, data modeling, Process Modeling and Strategic Development are carried out.

3. Designing. At this stage the design is divided into three designs, namely user interface design, database design, and algorithm design.

4. System Implementation. The implementation stage is carried out with the aim of finding out whether the design designed to meet the system can operate properly or not.

\section{Research Methods}

\subsection{Preparation}

The preparation stage in this research consists of several stages. the first stage is the observation of the object of research to find out the existing problems. the second stage is a literature study on Quality function deployment, system development life cycle and figma. the third stage is the identification of problems that occur in the object of research. The fourth stage is problem formulation. The problems that occur in the object of research are then formulated into question sentences to find answers in this study. The final step in this preparation is the setting of research objectives. At this stage the research objectives are determined to be a benchmark for the success of this research, helping researchers focus the research direction and determine the targets to be achieved.

\subsection{Data Collection}

The data used in this study are divided into 2 types of data:

1. The primary data in this study came from filling out questionnaires by respondents. The results of filling out the questionnaire are used to determine the Voice of Customer and to determine the level of importance of each attribute in the design of the application system.

Table 3. Attributes of VOC questionnaire.

\begin{tabular}{|c|l|}
\hline No & \multicolumn{1}{|c|}{ Attribute } \\
\hline 1 & Shop through the app \\
\hline 2 & Balance for transactions \\
\hline 3 & Discount information \\
\hline 4 & Reference to the use of batik tulis models \\
\hline 5 & Batik learning information \\
\hline 6 & $\begin{array}{l}\text { Information on directions to the village of } \\
\text { Giriloyo batik }\end{array}$ \\
\hline 7 & $\begin{array}{l}\text { Information about the profile of Giriloyo } \\
\text { batik village }\end{array}$ \\
\hline 8 & Application security \\
\hline 9 & Attractive appearance \\
\hline
\end{tabular}

The sample size calculation is done using the following formula calculation:

$$
\mathrm{n}=\frac{Z^{2} \cdot p(1-p)}{E^{2}}
$$

$\mathrm{n}=$ Number of sample, $\mathrm{Z}=$ The value depends on the level of confidence used, $p(1-p)=$ Population variation (if unknwon, the $\mathrm{p}$ value is assumed to be 0.5 ), $\mathrm{E}=$ sampling error.

2. Secondary data includes data from interviews and other sources, such as the results of previous studies, journals, and others that are used to obtain and explore theories that can support research problem solving.

\subsection{Data Processing}

After the data is collected, data processing must be carried out so that it can be analyzed and conclusions are found to answer the problems in this research. Data processing carried out is a validity test using an accuracy rate of $10 \%$, reliability testing to find out the information to be used can be trusted as a data collection tool and is able to describe the actual information. Data that is declared valid and reliable is then processed in the quality function deployment tool by following the stages of the house of quality. The last stage in the data processing process is system design. This system design follows the stages in the system development life cycle method. 


\subsection{Final Stage}

This stage is the last stage of the research. This stage consists of conclusions obtained from data processing and analysis in the previous stage. There are also constructive suggestions for the company and for further researchers in order to obtain improvements in further research.

\section{Result and Discussion}

\subsection{Validity and reliability testing}

Based on the calculation using formula (3), the result of the number of samples to fill out the questionnaire was 67.65. for errors, the sample is rounded up to 70 .VOC data obtained from the questionnaire was then tested for validity and reliability testing. all variables in the questionnaire were declared valid $\mathrm{R}$ count $\geq \mathrm{R}$ table $(0.235)$. For reliability testing cronbach alpha $(0.744) \geq$ 0.60. All variables are declared reliable. Therefore all variables can be used in the next process.

\subsection{Data processing using the house of quality tools}

\subsubsection{Customer Importance.}

Customer Importance aims to determine the weight of each attribute of the questionnaire. The weight of the resulting questionnaire is useful to determine the priority of consumer needs that must be met in the application.

Table 4. Importance Rating Results.

\begin{tabular}{|c|l|c|}
\hline No & \multicolumn{1}{|c|}{ Atribut } & $\begin{array}{c}\text { Importance } \\
\text { Rating }\end{array}$ \\
\hline 1 & Shop through the app & 4.76 \\
\hline 2 & Balance for transactions & 4.17 \\
\hline 3 & Discount information & 4.06 \\
\hline 4 & $\begin{array}{l}\text { Reference to the use of batik } \\
\text { tulis models }\end{array}$ & 3.90 \\
\hline 5 & Batik Learning Information & 3.26 \\
\hline 6 & $\begin{array}{l}\text { Information on directions to } \\
\text { the village of Giriloyo batik }\end{array}$ & 3.70 \\
\hline 7 & $\begin{array}{l}\text { Information about the profile } \\
\text { of kampung batik Giriloyo }\end{array}$ & 3.29 \\
\hline 8 & Application security & 4.51 \\
\hline 9 & Attractive appearance & 4.57 \\
\hline
\end{tabular}

In table 2 above the highest weights that must be met in the application are shop through the app, attractive appereance and then according to the value of each attribute.

\subsubsection{Technical Responses.}

Technical responses are answers to consumer needs. The technical response is shown in the table below:
Table 5. Control To Quality.

\begin{tabular}{|l|l|}
\hline No. & Technical Responses \\
\hline 1 & Fitur Shop \\
\hline 2 & Fitur E-pay \\
\hline 3 & Discount information \\
\hline 4 & Batik Of the Day \\
\hline 5 & Nyanting \\
\hline 6 & Fitur Locator \\
\hline 7 & Fitur MyBatik \\
\hline 8 & Fitur Account \\
\hline 9 & Attractive UI design \\
\hline
\end{tabular}

\subsubsection{Relationship Matrix.}

This relationship matrix is used to determine the relationship between VOC and technical responses. At this stage, measurement of the influence of the responses technique on VOC is carried out.

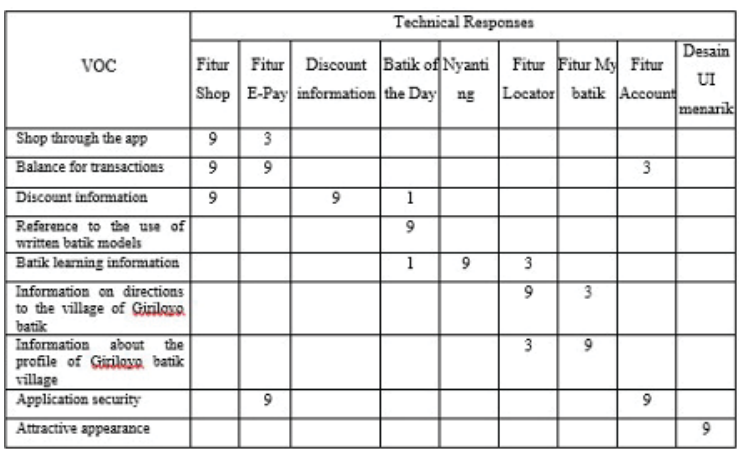

Fig.1. Relationship Matrix

\subsubsection{Customer Rating.}

The customer rating in this study was not carried out because the results of this study were still in the form of a design so that it could not be measured and compared with other existing store applications.

\subsubsection{Technical Correlation.}

This relationship matrix is used to determine the relationship between VOC and technical responses. At this stage, measurement of the influence of the responses technique on VOC is carried out.

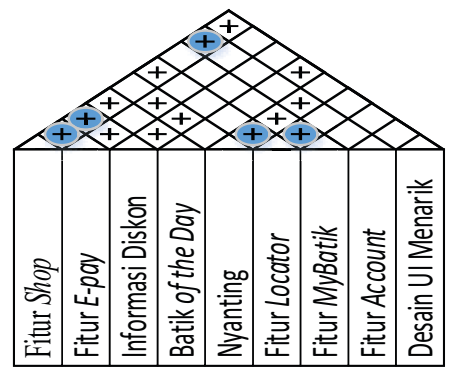

Fig.2. Technical Correlation 


\subsubsection{Technical Priorities.}

The main priority of technical responses that must be prioritized in system development is calculated at the technical priorities stage. There are 2 calculations in this stage, namely absolute importance (AI) and relative importance (RI). The results of the two calculations are summarized in the table below:

Table 6. Technical Priorities

\begin{tabular}{|c|l|c|c|}
\hline No & $\begin{array}{l}\text { Technical } \\
\text { Responses }\end{array}$ & AI & RI \\
\hline 1 & Fitur Shop & $\begin{array}{c}116,9 \\
1\end{array}$ & $23 \%$ \\
\hline 2 & Fitur E-Pay & 92,4 & $18 \%$ \\
\hline 3 & $\begin{array}{l}\text { Informasi } \\
\text { Diskon }\end{array}$ & 36,54 & $7 \%$ \\
\hline 4 & Batik of the Day & 42,42 & $8 \%$ \\
\hline 5 & Nyanting & 29,34 & $6 \%$ \\
\hline 6 & Fitur Locator & 52,95 & $10 \%$ \\
\hline 7 & Fitur Mybatik & 40,71 & $8 \%$ \\
\hline 8 & Fitur Account & 53,1 & $11 \%$ \\
\hline 9 & $\begin{array}{l}\text { Attractive UI } \\
\text { Design }\end{array}$ & 41,13 & $8 \%$ \\
\hline
\end{tabular}

\subsection{Program Design}

The application to be designed is a mobile application or application that can be accessed using a smartphone. This application has 7 features, namely shop features, epay, batik of the day, nyanting, locator, mybatik, accounts as described in the QFD technical responses stage. This application also has 5 main menus, namely home, nyanting, shop, locator and my batik. Below is the process modeling of the application:

Table 7. Process Modelling

\begin{tabular}{|l|l|}
\hline Process & Process Rules \\
\hline Home & $\begin{array}{l}\text { Home automatically as the main display after } \\
\text { entering personal data to login. Displays on } \\
\text { the home include discount information, } \\
\text { reference information on the use of batik } \\
\text { products and product category searches. }\end{array}$ \\
\hline Nyanting & $\begin{array}{l}\text { In this nyanting feature, there is information } \\
\text { about learning batik and reservations for } \\
\text { learning batik. The reservation process can be } \\
\text { done by entering the requested data and } \\
\text { confirming the payment. }\end{array}$ \\
\hline Shop & $\begin{array}{l}\text { The shop process on the application can be } \\
\text { done by selecting the product category then } \\
\text { entering the delivery data and confirming the } \\
\text { payment. In the shop feature there is an E-pay } \\
\text { feature which is an alternative payment other } \\
\text { than via bank transfer. }\end{array}$ \\
\hline Locator & $\begin{array}{l}\text { The locator process can be done by activating } \\
\text { the location feature on the smartphone, then } \\
\text { the application can connect the customer's } \\
\text { location with the location of the Giriloyo } \\
\text { batik village. }\end{array}$ \\
\hline Mybatik & $\begin{array}{l}\text { The process in the mybatik feature is by } \\
\text { selecting the desired category of information } \\
\text { then the system will display the information. }\end{array}$ \\
\hline
\end{tabular}

\subsubsection{UI Design.}

UI design is done before the design implementation process using the figma application. The purpose of making this UI design is to simplify the design in the implementation process. below is an example of a UI design for the home menu.

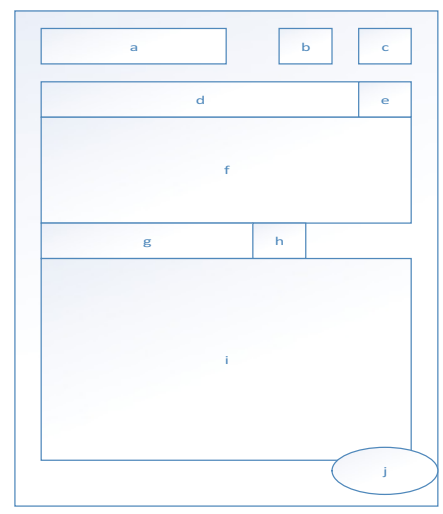

Fig. 3. UI Home

In the picture above there are buttons including: a.Mybatik, b.Home button, c. Locator button, d. Search, account, f. Discount product information, g. E-pay balance information, h. Top Up, i. Batik usage reference information, j.Shop button.

\subsubsection{Database Design.}

The database on this sales application is described through the Ebtity Relation Diagram (ERD). below is a series of ERD in the design of the application model: 1. Entity List

Table 8. Process Modelling

\begin{tabular}{|l|l|}
\hline \multicolumn{1}{|c|}{ Entitas } & \multicolumn{1}{c|}{ Attribute } \\
\hline Shop & $\begin{array}{l}\text { Picture_product, name_product, } \\
\text { price_product,description_product }\end{array}$ \\
\hline E Pay & Balance,top_up method \\
\hline Account & Photo_account, User_name \\
\hline Locator & $\begin{array}{l}\text { User_location,kampung_batik_location, } \\
\text { navigation }\end{array}$ \\
\hline $\begin{array}{l}\text { Batik of the } \\
\text { day }\end{array}$ & $\begin{array}{l}\text { Outfit_photo,Outfit_Description, } \\
\text { product_name }\end{array}$ \\
\hline Mybatik & $\begin{array}{l}\text { Location_photo,kampung_batik_profile, } \\
\text { job_vacancy_name,job_vacancy_specifi } \\
\text { cation,research_submission_flow }\end{array}$ \\
\hline $\begin{array}{l}\text { Discount } \\
\text { information }\end{array}$ & $\begin{array}{l}\text { Product_name, price_before_discount, } \\
\text { price_after_discount,discount amount }\end{array}$ \\
\hline Nyanting & $\begin{array}{l}\text { Batik_learning_data,nyanting_price,rese } \\
\text { rvation }\end{array}$ \\
\hline
\end{tabular}

\section{Relation}

At this stage, each entity is connected based on the technical correlation in the QFD. The following is a table that describes the relationship between entities in the Giriloyo batik sales application: 
Table 9. Relationship

\begin{tabular}{|l|l|l|}
\hline Entity 1 & Relation & Entity 2 \\
\hline Shop & $\begin{array}{l}\text { Have a } \\
\text { relationship }\end{array}$ & Epay \\
\hline Epay & $\begin{array}{l}\text { Have a } \\
\text { relationship }\end{array}$ & Shop \\
\hline Nyanting & $\begin{array}{l}\text { Have a } \\
\text { relationship }\end{array}$ & Mybatik \\
\hline Locator & $\begin{array}{l}\text { Have a } \\
\text { relationship }\end{array}$ & Mybatik \\
\hline Account & $\begin{array}{l}\text { Have a } \\
\text { relationship }\end{array}$ & Epay \\
\hline Mybatik & $\begin{array}{l}\text { Have a } \\
\text { relationship }\end{array}$ & Nyanting,locator \\
\hline
\end{tabular}

\subsubsection{Algorithm design.}

Below is the home menu algorithm design:

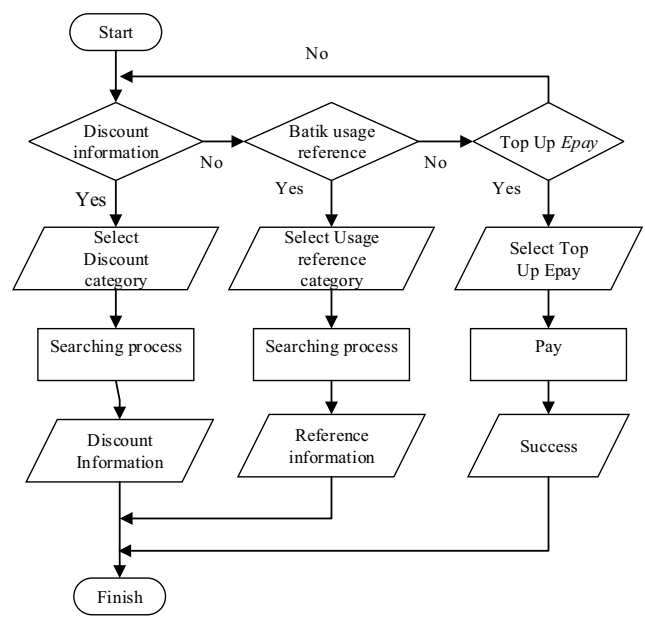

Fig.4. Home algorithm

\subsubsection{Implementation.}

At the implementation stage, a prototype appli cation design was made using figma software.

Below is an application design using figma:

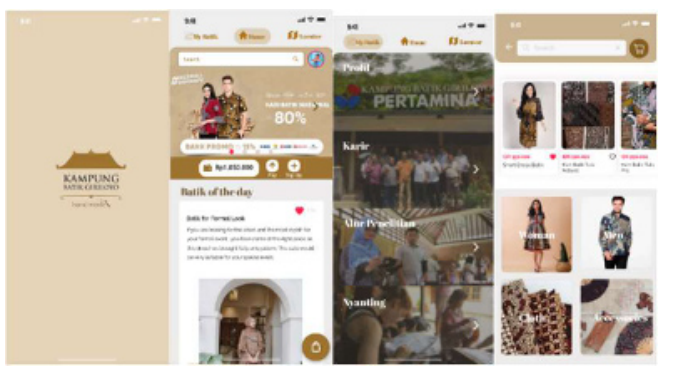

Fig.5. Application Prototype Display

\section{Conclusion}

Based on the measurements and calculations as well as the discussion carried out, it can be concluded as follows:
1. Based on the results of the customer needs questionnaire (attached) which is processed using the House of Quality, customer needs are obtained, namely: Shopping through applications, Balance for transactions, There is discount information, There is reference information on the use of batik tulis models, There is information on learning to make batik, Information on directions to the village of Giriloyo batik , Information on the profile of Giriloyo batik village,Application security ,attractive appearance.

2. The weight of importance of customer needs based on the calculation of importance Rating obtained the following results: Shop through the app: 4.76, Balance for transactions: 4.17, Discount information: 4.06, Reference to the use of batik tulis models: 3.9, Batik learning information: 3.26, Information on directions to the village of Giriloyo batik: 3.7, Information about the profile of Giriloyo batik village: 3.29 , Application security: 4.5 dan Attractive appearance: 4.57 .

3. Designing application prototypes to meet customer needs based on technical responses is shop features, epay features, discount information, batik of the day, nyanting, locator features, my batik features, account features and attractive designs.

\section{References}

[1] Antari M T P and Adriyanto A R 2018 Perancangan Prototype Aplikasi Mobile Dan Model Bisnis Untuk Pemesanan Oleh-Oleh Khas Bandung Computer,Mathematics and Engineering Applications, 11(1) (Bandung: Universitas Telkom) pp. 2069, (2077).

[2] As'adi M et al 2020 Kajian Model Desain Aplikasi Mobile Yang Berkelanjutan Study Of Sustainable Mobile Application Design Models In Tourism Villages Jurnal Manajemen Industri dan Logistik Vol. 04 (Jakarta: Politeknik APP Jakarta) pp. 47-57

[3] Doellah H S 2002 Batik: Pengaruh Zaman dan Lingkungan (Solo: Danar Hadi)

[4] Erdil N O and Arani O M, Quality Function Deployment: More Than A Design Tool International Journal of Quality and Service Sciences, 11(2), pp. 142-166, (2019).

[5] Pressman 2009 Software Engineering: A Practitioner's Approach (New York: McGrawHill)

[6] Suwintana I K, Sudhana I G P F P and Hariyanti N K D 2018 Pengembangan Aplikasi Mobile Teller Lembaga Perkreditan Desa Berbasis Android Matrix Jurnal Manajemen Teknologi dan Informatika p. 59 